\title{
Do 5-star hotel managers know their customers' priorities? An AHP-Prioritised scorecard study
}

\author{
Alessio Ishizaka ${ }^{a}$, Alfred Quintano $^{b}$, Ashraf Labib $^{a}$, Alexandros Apostolakis $^{c}$ \\ a University of Portsmouth, Centre for Operational research and Logistics, Portsmouth Business School, \\ Richmond Building, Portland Street, PO1 3DE Portsmouth, United Kingdom \\ ${ }^{\mathrm{b}}$ University of Malta, Institute for Tourism, Travel \& Culture, Msida MSD2080, Malta \\ ${ }^{\mathrm{c}}$ Technological Educational Institute of Crete, School of Management and Economics, Department of \\ Business Administration, Heraklion 71410, Crete, Greece.
}

\begin{abstract}
Purpose: Regular surveys by the Malta Hotels \& Restaurants Association (MHRA) indicate a substantial improvement in financial performance of 5-star hotels in Malta in recent years. Therefore, this study investigates if this positive performance is primarily due to customercentricity by management.

Design/methodology/approach: The assessment is based on the findings of a quantitative study that compared the results of a demand-side (customer survey) with those of a supply-side (management survey). Twenty-four decision-choice criteria were framed within the four perspectives (financial, customer, internal process, and employee learning/growth) of the balanced scorecard. Actual and potential customers of 5-star hotels and hotel managers were asked to rank the decision-choice criteria and the balanced scorecard perspectives. The multicriteria decision analysis was carried out by means of the AHP.
\end{abstract}

Findings: The study showed that managers in the 5-star hospitality sector in Malta are in harmony with customer expectations given the strong positive correlation between the results of the customer and management surveys.

Research limitations/implications: This research is limited to the island of Malta but can be easily replicated for other touristic destinations.

Practical implications: This study has implication for hospitality customers, hotel managers and policy makers to help them to identify weak areas of hotel performance and improve them.

Originality/value: The paper has developed a Prioritised scorecard, a new hybrid balanced scorecard and AHP. Targets are therefore prioritised, which allow a better allocation of scarce resources. 
Keywords: Hotel management; 5-star hotels; Malta; analytic hierarchy process; balanced scorecard.

\section{Introduction}

Customer satisfaction is often considered the ultimate goal in the services industry since it significantly impacts the corporative image and financial performance of the companies. Customer satisfaction leads to customer loyalty and it is the cheapest form of promotion as it attracts more customers through recommendations (Assaf et al., 2015). However, it also creates the challenge of maintaining high levels of service, awareness of customer expectations and a consistent improvement in the service offer (Pizam et al., 2016). Customer satisfaction is evaluated by measuring the extent to which services meet customers' expectations. To be successful, companies need to create a customer-oriented approach, where they focus on the needs of a specific customer segment. Fulfilling customer expectations means that companies need to know what their customers want and be proactive towards the implementation of a continuous feedback routine mechanism to inform the decision making process.

However, this task is difficult as there are many customers and criteria to fulfil. Several hotels use the balanced scorecard approach (Elbanna et al. 2015). A balanced scorecard includes four perspectives: financial, learning and growth, internal processes and customer perspective. In fact, relying solely on financial measures is inadequate as it is short-term oriented. Financial metrics reflect past actions of the organisation but they cannot identify areas of strategic improvement and innovation (Kaplan, 2008). They are insufficient for customer-oriented organisations and in particular hotels. However, in a balanced scorecard, all the dimensions are considered to have the same importance, which does not give any indication to the manager on which dimension to prioritise.

The aim of this paper is to propose an integrated method for prioritising strategic targets, which can be used for evaluating the demand and supply sides of a business. In particular we propose to use the Analytic Hierarchy Process method (henceforth AHP), which is more precise than a direct evaluation and has an integrated mechanism to check the consistency of participants' responses and is also capable of providing sensitivity (What if) analysis (Ishizaka and Labib, 2011). We applied this AHP-Prioritised scorecard to the 5-star hotel sector in Malta. The study sets out to test the hypothesis that managers in 5-star hotels in Malta are aware of their customers' priorities. This is done by means of a demand-side survey of actual and potential 5-star hotel customers, complemented by a supply-side survey targeting managers working in 5-star hotels in Malta. Strong positive correlation between survey results is noted and consequently practical implications of the research findings are drawn and a way forward is proposed for the 5-star hospitality sector in Malta. 
Section 2 of the paper deals with the literature review. Section 3 introduces the research background and section 4 presents the methodology. Section 5 deals with the empirical results while section 6 provides a number of practical implications for policy makers and practitioners in the field. Finally, section 7 concludes the paper.

\section{Previous studies using AHP in the tourism and hospitality literature}

Customers often have several criteria that need to be satisfied concurrently, therefore multicriteria decision making methods have often been used. ENREF 47AHP is one of a number of Multi Criteria Decision Analysis (MCDA) methods. It was originally developed by Saaty (1980). In brief, it is a method to derive ratio scales from paired comparisons. The AHP method has been found to be more precise than simple direct questions (Millet, 1997, Whitaker, 2007) because respondents can focus on only two elements at a time. It also incorporates an inconsistency measure to cross-check the validity of the answers and a sensitivity analysis (Ishizaka and Labib, 2011). It also permits to structure clearly the problem in a hierarchy (Saaty, 1980). A recent experimental study shows that AHP is more precise compared to other MCDA method (Ishizaka and Siraj, 2018). Tsaur and Tzeng (1996) evaluated customer decision criteria in selecting Taiwanese hotels with Analytic Hierarchy Process (AHP). AHP has later been used to evaluate the importance of criteria determining the location of a thermal hotel (Emir and Saraçli, 2014). Hsiao et al., (2018) used AHP and the Delphi method to assess the indicators for the Bed and Breakfast development. It has also been used in the selection of a resort location in a three-step application (Juan and Lin, 2013) where the evaluation criteria were elicited using the Delphi method. Thereafter, the twenty-four selected criteria were prioritised with AHP by nineteen experts and, in the final stage, a sensitivity analysis (what-if analysis) was performed to assess the robustness of the results.

The AHP in hospitality studies has also often been combined with other methods. Shirouyehzad et al. (2013) used an integrated AHP/Data Envelopment Analysis (DEA) hybrid ranking method to evaluate service quality in a 5-star hotel. A hybrid model using two primary Multi-Criteria Decision Analysis tools, namely the AHP and PROMETHEE, was used to evaluate 5-star hotel websites (Akincilar and Dagdeviren, 2014). In this case, the AHP was utilised to weigh the selected criteria, and the ranking of the alternatives was carried out via PROMETHEE. A similar study evaluated and ranked hospitality internet services with Webqual and fuzzy AHP (Shahin et al., 2014). The hybrid SWOT analysis and AHP was used for the formulation of future tourist orientation (Fabac and Zver, 2011) and nine recreational areas (Lee and Liu, 2011). A study on the evaluation of the relative importance of hotel website functionality criteria and sub-criteria was done with fuzzy AHP (Ip et al., 2012).

Another study included the application of fuzzy AHP and VIKOR to hospitality performance analysis (Fu et al., 2011). The determination of the best marketing strategy for private hotels was analysed using a fuzzy AHP approach in order to optimise the use of scarce resources (Sohrabi et al., 2012). Chen et al. (2012) and Tsaur and Lin (2014) used the same approach for respectively evaluating 
the criteria for giving an excellent hotel spa ambience and the criteria for the selection of an overseas travel intermediary for group package tours. Roy et al. (2018) used AHP and rough numbers to evaluate medical tourism sites. Table 1 summarises the applications of AHP in the hotel industry. It is to be noted that AHP has been often applied in conjunction other techniques.

Table 1: Applications of AHP in the hotel industy

\begin{tabular}{|c|c|c|}
\hline Authors & Technique & Research Context \\
\hline Tsaur and Tzeng (1996) & AHP & $\begin{array}{l}\text { Evaluation of customer decision } \\
\text { criteria in selecting Taiwanese hotels }\end{array}$ \\
\hline Emir and Saraçli (2014) & AHP & $\begin{array}{l}\text { Evaluation of criteria for determining } \\
\text { the location of a thermal hotel }\end{array}$ \\
\hline Hsiao et al, (2018) & AHP and Delphi method & $\begin{array}{l}\text { Evaluation of indicators for the Bed } \\
\text { and Breakfast development }\end{array}$ \\
\hline Juan and Lin (2013) & $\begin{array}{l}\text { Delphi method, AHP and } \\
\text { what-if analysis }\end{array}$ & Selection of a resort location \\
\hline $\begin{array}{l}\text { Shirouyehzad et al. } \\
\text { (2013) }\end{array}$ & AHP and DEA & $\begin{array}{l}\text { Evaluation of the service quality in a 5- } \\
\text { star hotels }\end{array}$ \\
\hline $\begin{array}{l}\text { Akincilar and Dagdeviren } \\
\text { (2014) }\end{array}$ & AHP and PROMETHEE & Evaluation of 5-star hotel websites \\
\hline Shahin et al. (2014) & Webqual and fuzzy AHP & $\begin{array}{l}\text { Evaluation of hospitality internet } \\
\text { services }\end{array}$ \\
\hline Fabac and Zver (2011) & SWOT analysis and AHP & $\begin{array}{l}\text { Formulation of future tourist } \\
\text { orientation }\end{array}$ \\
\hline Lee and Liu (2011) & SWOT analysis and AHP & Formulation of nine recreational areas \\
\hline Roy and al. (2018) & AHP and rough numbers & Evaluation of medical tourism sites \\
\hline Ip et al. (2012) & fuzzy AHP & $\begin{array}{l}\text { Evaluation of the relative importance } \\
\text { of hotel website functionality criteria }\end{array}$ \\
\hline Fu et al. (2011) & fuzzy AHP and VIKOR & Hospitality performance analysis \\
\hline Sohrabi et al. (2012) & fuzzy AHP & $\begin{array}{l}\text { Determination of the best marketing } \\
\text { strategy for private hotels }\end{array}$ \\
\hline Chen et al. (2012) & fuzzy AHP & $\begin{array}{l}\text { Evaluation of the criteria for giving an } \\
\text { excellent hotel spa ambience }\end{array}$ \\
\hline Tsaur and Lin (2014) & fuzzy AHP & $\begin{array}{l}\text { Evaluation of the criteria for the } \\
\text { selection of an overseas travel } \\
\text { intermediary for group package tours }\end{array}$ \\
\hline $\begin{array}{l}\text { Sharma and Bhagwat } \\
\text { (2007) }\end{array}$ & $\begin{array}{l}\text { AHP and balanced } \\
\text { scorecard }\end{array}$ & Evaluation of supply chains \\
\hline Lin and Lin (2011) & $\begin{array}{l}\text { AHP and balanced } \\
\text { scorecard }\end{array}$ & Evaluation of tourist hotels \\
\hline Kim et al. (2014) & $\begin{array}{l}\text { AHP and balanced } \\
\text { scorecard }\end{array}$ & Evaluation of hotel websites \\
\hline
\end{tabular}

In this paper, we combine the balanced scorecard and AHP methods as described in Clinton et al. (2002). The paper then applies this combination to 5-star hotels in Malta from the point of view of the principal demand and supply side hospitality industry stakeholders, namely customers and 
hotel managers. This hybrid method is used when some perspectives in the balanced scorecard may be perceived to be more important than others and this is typically the case in the hospitality industry (Elbanna et al., 2015). Similarly, some criteria are also more relevant than others and hence the need of prioritisation with AHP. Previously, this combination was used to evaluate five supply chains, including one from the food and beverage industry (Sharma and Bhagwat, 2007). It was also used to evaluate hotels (Lin and Lin, 2011) and hotel websites (Kim et al., 2014). In our study, customers and managers of 5-star hotels in Malta evaluated twenty-four criteria framed within the four perspectives of the balanced scorecard.

\section{Research background}

The research study was conducted in Malta, which is considered an ideal tourism and hospitality research location due to its diverse tourism source markets and relatively low seasonality. In 2017 the island of Malta attracted 2.3 million visitors who stayed 16.5 million nights. The 5-star hotel sector in Malta, comprising fifteen hotels representing $28 \%$ of all bed-stock, has performed exceptionally well in recent years. Occupancy levels and achieved average room rates (AAR) grew steadily, and gross operating profit per available room (GOPAR) more than tripled between 2009 and 2017 from $€ 7,514$ to $€ 24,320$ according to the Malta Hotels \& Restaurants Association (MHRA, 2018, MHRA, 2010). Hotels in similar tourism destinations, such as the Spanish Costas in the Alicante region, only experienced minor improvement during the same period (Babayan et al., 2014). The difference in improvement rate is presented in Table 2.

Table 2: Key performance indicators: 5-star hotels in Malta and Spain (Costas).

\begin{tabular}{|l|l|l|l|l|}
\hline \multirow{2}{*}{ Year } & \multicolumn{2}{|l|}{ MALTA } & \multicolumn{2}{l|}{ SPAIN (Costas) } \\
\cline { 2 - 5 } & Occupancy (\%) & ARR (€) & Occupancy $(\%)$ & ARR $(€)$ \\
\hline 2010 & $64.6(+6.6 \mathrm{pp})$ & $98.1(+7.0 \%)$ & $54.9(+5.8 \mathrm{pp})$ & $120.0(+3.2 \%)$ \\
\hline 2011 & $66.7(+2.1 \mathrm{pp})$ & $101.6(+3.6 \%)$ & $58.4(+3.5 \mathrm{pp})$ & $121.1(+0.1 \%)$ \\
\hline 2012 & $68.2(+1.5 \mathrm{pp})$ & $105.3(+3.6 \%)$ & $58.7(+0.3 \mathrm{pp})$ & $122.3(+0.1 \%$ \\
\hline 2013 & $69.6(+1.4 \mathrm{pp})$ & $111.8(+6.2 \%)$ & $61.6(+2.9 \mathrm{pp})$ & $123.1(+0.2 \%)$ \\
\hline 2014 & $74.2(+4.6 \mathrm{pp})$ & $119.4(+6.7 \%)$ & $62.9(+1.3 \mathrm{pp})$ & $125.6(+0.2 \%)$ \\
\hline 2015 & $76.0(+1.8 \mathrm{pp})$ & $135.0(+12.5 \%)$ & $70.5(+7.6 \mathrm{pp})$ & $135.0(+10.8 \%)$ \\
\hline 2016 & $76.0(\mathrm{n} / \mathrm{c} \mathrm{pp})$ & $142.0(+5.2 \%)$ & $74.0(+3.5 \mathrm{pp})$ & $140.0(+3.7 \%)$ \\
\hline 2017 & $76.8(+0.8 \mathrm{pp})$ & $157.7(+11.0 \%)$ & $76.4(+2.4 \mathrm{pp})$ & $152.0(+8.6 \%)$ \\
\hline
\end{tabular}

Source: MHRA, 2018; INE, 2018.

The improved performance of 5-star hotels in Malta happened in the context of a substantially changed operational scenario. In this setting, the source of bookings for Malta visits changed from $66 \%$ tour operator based packages versus 34\% individual booking in 2006 (NSO, 2007) to 40\% tour operator based packages versus 60\% individual bookings in 2017 (NSO, 2018) driven by the arrival of direct online sale and online virtual travel agencies such as Expedia, Booking.com, Opodo (Law 
et al., 2015). This process of disintermediation required a change to a customer-centric approach by hotel managers, instead of focusing exclusively on tour operators. This entailed their full cognizance of what the individual customer expects from a 5-star hotel. To investigate this argument further, the analysis employed a balanced scorecard based survey. The balanced scorecard has been widely used in the hotel industry for strategic planning (Jackson and Qu, 2008, Kang et al., 2015, Elbanna et al., 2015, Sainaghi et al., 2013). In the balanced scorecard, the organization is viewed from four independent perspectives. The four perspectives are:

Financial: this perspective views organizational financial performance and the use of financial resources

Customer: this perspective views organizational performance from the point of view of the customer

Internal Process: views organizational performance through the lenses of the quality and efficiency related to the product or services or other key business processes

Learning and growth (employee): views organizational performance through the lenses of human capital, infrastructure, technology, culture and other capacities that are key to breakthrough performance

The management or all staff in a participative approach will then develop attributes or Key Performance Indicators (KPIs) and initiatives (actions) relative to each of these perspectives. However, the balanced scorecard does not provide weightings for the attributes nor the relative importance between the four perspectives. Moreover, it does not permit incorporation of different views from different types of stakeholders regarding their preferences. To fulfil our research aim, prioritization of the four balanced scorecard perspectives is introduced in this study as also a prioritized ranking of criteria used by customers in choosing a 5-star hotel.

\section{Methodology}

To determine the most important criteria in selecting a superior hotel, a three steps method was followed in this study. As a first step, the criteria were listed, then they were framed in the four perspectives of the balanced scorecard and finally they were evaluated using the AHP.

\subsection{Elicitation of criteria}

As an initial step in this study, a set of twenty-four decision-choice criteria considered in the process of selecting a 5-star hotel were determined through a process of elicitation in a series of six stakeholder focus groups ranging in size from 8 to 12 participants. Management focus groups were carried out in all four 5-star hotels in Malta that agreed to participate in the study. It was imperative that in-house focus groups include participation by the broadest spectrum of 
management and staff ranging from the hotel general manager to food \& beverage attendants (waiters) and room attendants (chambermaids) as the latter were familiar with the internal processes and experience the 'moments of truth' (Carlzon, 1987)or 'touch-points' in guest interaction. The rationale to open up to all staff members is that each one have their own customer experiences and may have different views on what criterion is important. For recruiting the participants, the six focus groups have been largely advertised by the human resources of the hotels through emails and in staff meetings. Attendance was voluntary.

Guest focus groups were carried out in two hotels just prior to the General Manager's 'welcome' drinks. One group had 25 participants and the second 32.

The focus groups proceeded according to the guidelines set by Skinner (2009). They lasted around 30 minutes for the management focus group and slightly longer for the guest focus group. The steps followed in these meetings were the following:

Step 1: Explanation of why the researchers are eliciting criteria and how they will be used. (Around 5 minutes)

Step 2: Each participant writes down one criterion on a sticky note, which is placed on the wall and this continues until all have elicited all their criteria. Only one criterion per note is allowed as these will be grouped under four 'perspectives' in step 3. (Around 10 minutes)

Step 3: After collecting the criteria, the research team works on grouping the criteria. The grouping should focus around a common theme, e.g. grouped under the four BSC perspectives. (Around 10 minutes)

Step 4: After grouping the criteria, redundant criteria are removed. Low relevant criteria are also discarded. They were not many and were related to strictly intra-departmental issues. The reason for elimination was highlighted to proponents. It is important that, before eliminating a criterion, the proposer agrees with removing it. (Around 5 minutes)

\subsection{The balanced scorecard}

The twenty-four criteria elicited in the focus groups were then framed within the four perspectives of the balanced scorecard as shown in Figure 1, namely the 'customer', 'learning and growth', the 'internal business process' and the 'financial' perspectives (Kaplan and Norton, 1996). A hierarchy is built with the upper level denoting the four perspectives of the balanced scorecard and the lower level denoting the twenty-four elicited criteria. The 'learning and growth' perspective in the balanced scorecard effectively stands for the employee perspective in the business process (Kaplan, 2008). 


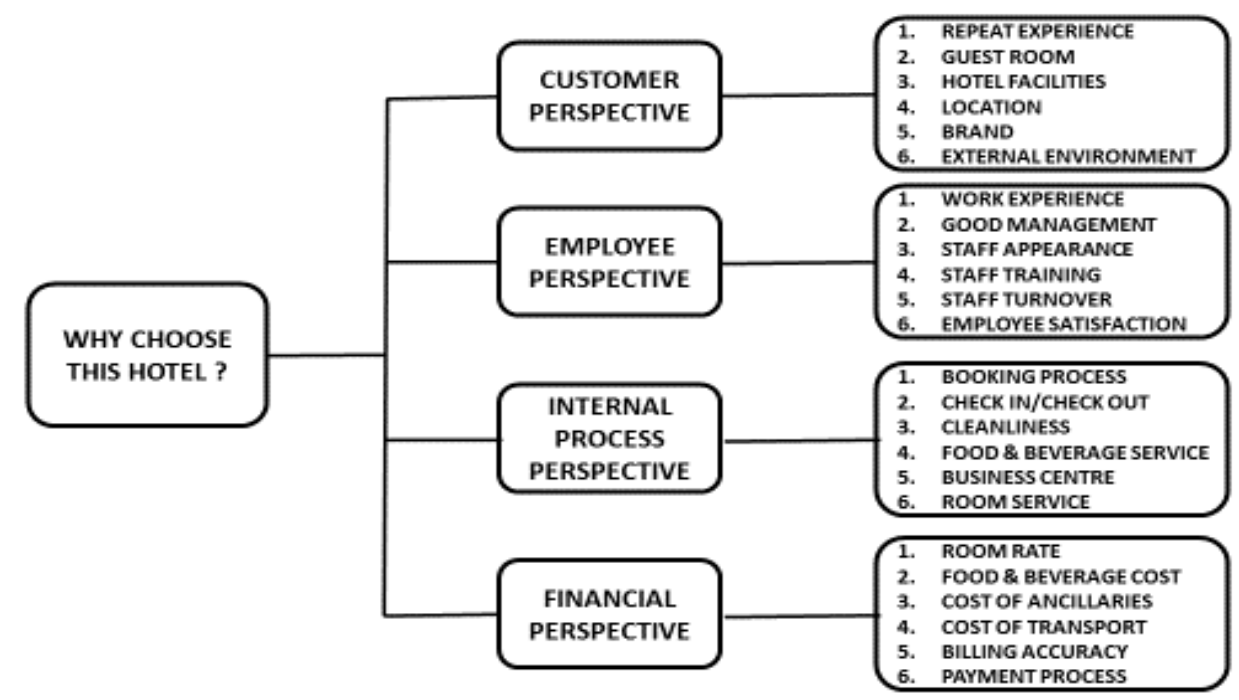

Figure 1. Hierarchy of the decision criteria.

Thereafter, two near identical surveys in Malta followed, in order to arrive at preference weightings of the four balanced scorecard perspectives and prioritisation of the twenty-four elicited criteria. The only distinguishing factor between the two survey questionnaires was the introduction. The survey presented the four balanced scorecard perspectives and the twenty-four criteria to actual and potential 5-star hotel customers, using a 9-point pair-wise comparison format of the AHP (Saaty, 1980). It is to be pointed out that the questionnaires included a space where respondents could add any further choice criteria not listed in the questionnaire. Of all respondents only one chose to propose a new criterion and that was 'snob value', which testifies to the completeness of the proposed list of criteria.

Customer survey administration followed strongly on the lessons learnt from a pilot survey. Three weeks into the pilot survey, it transpired that an element of strong subjectivity in the choice of respondents was evident given that Front Office (reception) hotel staff chose thirty-five particular clients at check-in whom they considered to be 'questionnaire-friendly'. This was most inappropriate. These questionnaires were discarded and the 'coffee table' method was adopted instead; this eliminated subjectivity and ensured a random distribution. The coffee table method of distribution of questionnaires is named after the supporting furniture holding the questionnaires. This new designation is inspired from the windshield method of distribution of questionnaires (Harris et al., 1979), where in this case the support is a car windshield. In our case, blank questionnaires were placed in four languages (English, Italian, German and French) on an attractively decorated table, strategically located between respective reception desks and the elevators. Guests picked up the questionnaire in the language of their choice, took the questionnaire to their room, filled it in at their convenience, and returned the completed questionnaire in an envelope supplied to reception. 
Following the customer survey, an electronic supply-side (management) survey was made that also used the same 9-point pair-wise comparison format of AHP (Ishizaka and Labib, 2011) as in the customer survey. This survey targeted 246 managers working in 5-star hotels in Malta using a data-base compiled through LinkedIn. 39 managers replied validly giving a response rate of $16 \%$.

\subsection{Prioritisation with the Analytic Hierarchy Process}

For the customer side, 866 questionnaires were distributed and 199 were returned, which makes a response rate of $23 \%$. In total 51 customer responses were discarded as invalid responses whereas 6 management survey replies were incomplete. The remaining 148 questionnaires from the customer survey and the 39 valid management responses were entered in the AHP software Expert Choice in the form of a pairwise comparison matrix A. From this matrix, the priorities $p$ can be calculated with the eigenvalue method (Saaty, 1980):

$$
A \cdot p=\lambda \cdot p
$$

where $\mathbf{A}$ is the comparison matrix

$\mathbf{p}$ is the priorities vector

$\lambda$ is the maximal eigenvalue

In AHP, a consistency index can be calculated:

$$
\mathrm{Cl}=\frac{\lambda_{\max }-n}{n-1}
$$

where $n=$ dimension of the matrix

$$
\lambda_{\max }=\text { maximal eigenvalue }
$$

If the $\mathrm{CR}$, ratio of $\mathrm{Cl}$ and $\mathrm{RI}$ (the average $\mathrm{Cl}$ of 500 randomly filled matrices), is less than $10 \%$, then the matrix can be considered as having an acceptable consistency.

$$
\mathrm{CR}=\mathrm{Cl} / \mathrm{RI}
$$

where $\mathrm{CR}$ is the consistency ratio

$\mathrm{RI}$ is the random index

Saaty (1977) calculated the following random indices:

\section{Table 3: Random indices}




\begin{tabular}{|l|l|l|l|l|l|l|l|l|}
\hline$n$ & 3 & 4 & 5 & 6 & 7 & 8 & 9 & 10 \\
\hline $\mathrm{RI}$ & 0.58 & 0.9 & 1.12 & 1.24 & 1.32 & 1.41 & 1.45 & 1.49 \\
\hline
\end{tabular}

Valid responses in this survey analysis are taken to mean the exclusion of those responses, six customers in total, that did not meet AHP consistency ratio (CR) $<10 \%$ threshold (Saaty \& Vargas, 2012). In a second round analysis, however, responses with a $C R<13 \%$ were reinstated and the outcome result was the same. This widened the sample size of the $5^{*}$ clientele to 148 whilst retaining the same outcome.

\section{Research findings}

The results of the two surveys are presented in this section.

\subsection{Demography}

The first survey was collected over a one-year period. Respondents actually accommodated in the four surveyed hotels represented $82 \%$ of all respondents, whereas the other $18 \%$ represented respondents that had resided in a 5-star hotel in Malta at some time in the past, or were planning to. The latter were primarily local Maltese who had stayed in a 5-star hotel. The rest were foreign visitors.

One of the important attributes of this study was the relatively long period of the survey exercise that lasted a full twelve months. The long survey period in this study was deemed to be essential in order to capture the full segmentation of the 2.3 million visitors per annum coming to Malta and the demographic diversity of its local population. The full-year survey period captured a cross section of visitor demographics, source market spread and, the purpose of travel. This ranges from pure leisure to business travellers and delegates attending meetings, incentives, conferences and events (MICE). The capture of inbound travellers visiting friends and relatives (VFR) was rather limited since these normally stay with family.

The choice of respondent profiling was driven by sampling for statistical relevance driven by a representative sample that mirrored the profiling used in the Tourism and Collective Accommodation data issued by the National Statistics Office (NSO) of Malta, in addition to unpublished sector-specific (i.e. 5-star only) data held by the Malta Tourism Authority (MTA) that was made available to the authors (Table 3 ). This statistical relevance, therefore, made for extrapolation of survey results to the total 5-star hotel guest population.

The overall gender segmentation of respondents in this survey shows that $59 \%$ of the participants were males. This is in line with unpublished statistics obtained from the Malta Tourism Authority (MTA) suggesting that the gender distribution in Malta's 5 star hotels was $58 \%$ male and $42 \%$ female.

The 18 to 35 age bracket staying in Malta 5 star hotels was of only 22\% which is understandable in the light of budgetary constraints. In the survey, they constitute $26 \%$ of the respondents. The age 
bracket 36 to 50 makes up $32 \%$ of all 5 star guests but $38 \%$ of all survey respondents. Lastly, it seems that the bulk, or $46 \%$ of guests in 5 star hotels in Malta form part of the seniors (51+) generation, whereas $36 \%$ responded to the survey.

A high percentage of survey respondents (72\%) classified themselves within the higher/intermediate managerial, administrative or professional category which is substantially higher than that recorded in surveys conducted by the Malta Tourism Authority (57\%). It may well be the case that within the broad range of upper middle and middle class lies a substantial segment of travellers that are comfortable staying in hotels of a lower classification (e.g. 4 star) rather than the exclusively 5 star hotels in which the survey was conducted.

The nationality spread of demand-side survey respondents in relation to stays in 5-Star hotels in Malta and total visitor numbers to Malta is shown in Table 4. The purpose of the visit is showed in Table 5.

Table 4: Nationality profile: demand-side survey

\begin{tabular}{|l|l|l|l|}
\hline Nationality: & Respondents & All 5*Hotels1 & Total Visitors \\
\hline Maltese & $(44) 31 \%$ & $18 \%$ & N/A \\
\hline British & $(38) 27 \%$ & $32 \%$ & $30 \%$ \\
\hline German & $(19) 13 \%$ & $10 \%$ & $10 \%$ \\
\hline Italian & $(13) 9 \%$ & $12 \%$ & $16 \%$ \\
\hline French & $(8) 6 \%$ & $7 \%$ & $7 \%$ \\
\hline Other & $(20) 14 \%$ & $21 \%$ & $39 \%$ \\
\hline
\end{tabular}

Table 5: Purpose of Visit in all 5-star hotels in Malta

\begin{tabular}{|c|c|c|}
\hline Purpose of Visit & Respondents & All $5^{*}$ Hotels ${ }^{1}$ \\
\hline Business & (25) $18 \%$ & $14 \%$ \\
\hline Special Interest & (12) $9 \%$ & $6 \%$ \\
\hline Leisure & (86) $60 \%$ & $50 \%$ \\
\hline M.I.C.E. & (10) $6 \%$ & $25 \%$ \\
\hline V.F.R. & (5) $4 \%$ & $3 \%$ \\
\hline Other & (4) $3 \%$ & $2 \%$ \\
\hline
\end{tabular}

1Source: Malta Tourism Authority, 2014.

The demographic data show that the surveyed guests are in line with the actual demography of the 5 star hotels in Malta.

\subsection{The four perspectives of the balanced scorecard}

Superior hotel customers feel that the 'customer' perspective carries by far the highest weighting, as illustrated in Figure 2. Consideration of 'financial' issues also features quite strongly particularly 
within the customer perspective. Customers give far less importance to the 'learning and growth' (employee) perspective and the 'internal business process' perspective, the latter being the interface between 'customer' and 'employee'. Ultimately, customers appear to be mostly interested in a satisfying outcome and not a process.

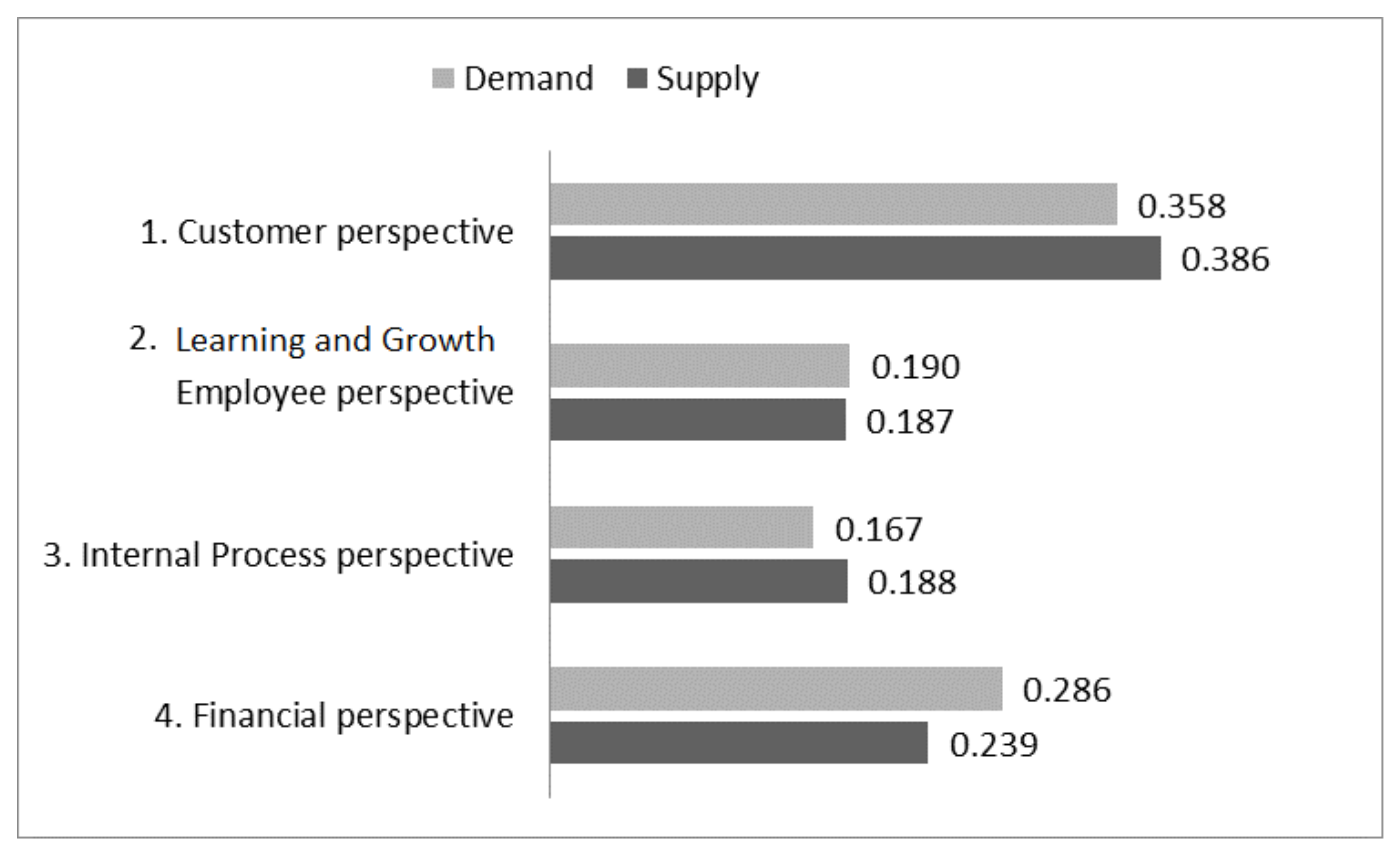

Figure 2. Balanced scorecard perspectives - demand- and supply-side weightings.

For hotel managers in Malta, the key perspective is by far the 'customer'. This indicates a customer-centric culture by management in the exercise of their duties. The three other perspectives are quite close. A marginally higher weighting is attributed to 'internal process' function than the 'learning and growth' (employee) perspective in recognition of their own managerial control function.

The comparison of both sides (Figure 2) indicates that the order of the perspectives is the same. However, a higher weighting is attributed by managers to the customer perspective, which recognises its fundamental importance.

\subsection{The 'customer' perspective}

As illustrated in Figure 3, the demand-side results confirm the old maxim, attributed to Conrad Hilton that the primary customer-oriented consideration in the mind of a potential guest when choosing a hotel is "location, location and location". The supply-side is also in agreement with the demand- side on location being the primary customer perspective decision-choice criterion. 
However, whereas for customers the second most important decision-choice criterion is the 'guest room', for hotel managers, the second most important criterion is 'repeat experience'. This 'repeat' or 'loyalty' criterion is ranked low in fifth position by customer respondents in the 'customer' perspective. This finding throws open a discussion on whether the hospitality sector over-stresses the relevance of 'loyalty marketing' with limited return on investment (ROI).

To brand or not to brand, that is the critical question faced by hotel owners and managers alike. Jackson and Qu (2008) consider the issue of brand management as a formidable challenge for hotels, hotel management companies, and hotel brand managers. They propose a framework based on BSC for a successful brand management. Moreover, the hospitality sector has seen some exponents argue that 'brand' has overtaken 'location' as the most important criterion in hotel selection (Callarisa et al., 2012). Chain-affiliation and riding on a global brand such as Hilton or Marriott has its advantages, however it does not come cheap (Wong and Wickham, 2015). The question arises as to whether ROI to hotel owners is positive following 'chain' branding or whether it pays to stay independent. Given the very low weighting and ranking given to 'brand awareness' by customer respondents; one wonders whether chain branding is 'money well spent'.

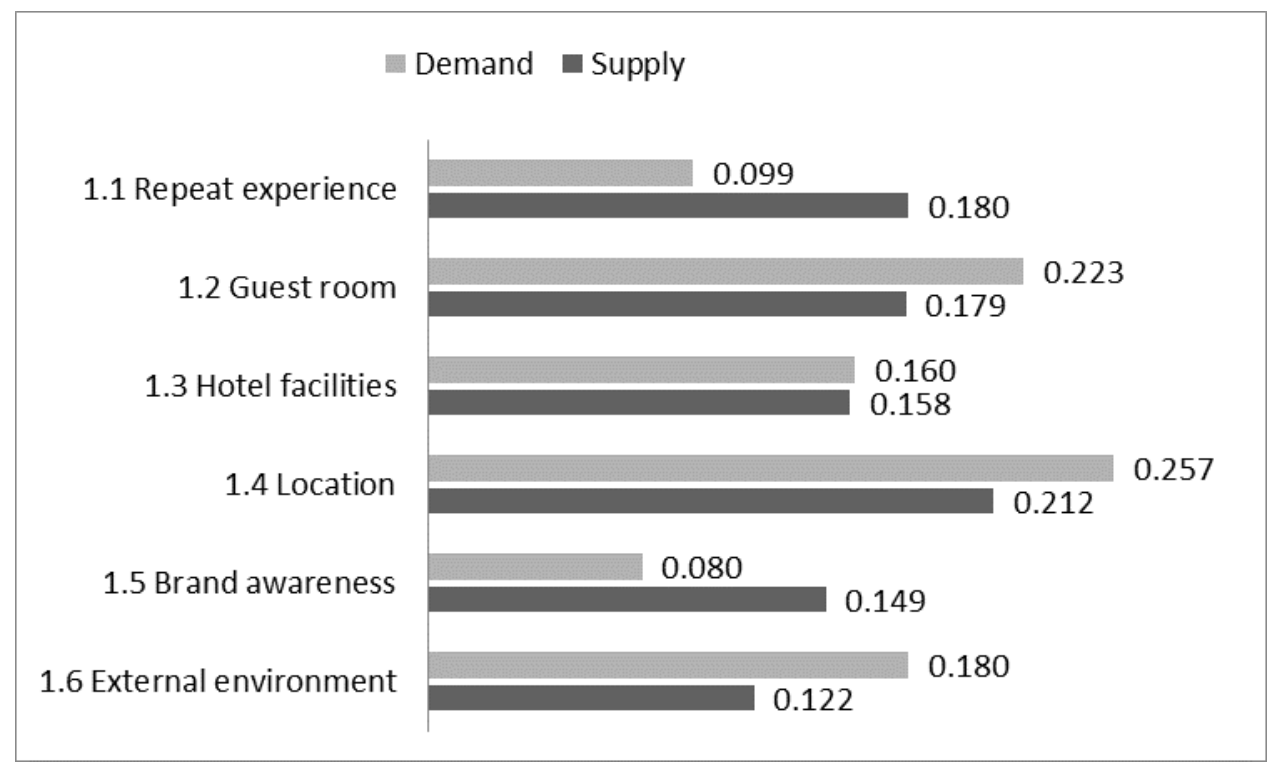

Figure 3. Customer perspective: demand- and supply-side weightings.

Another major difference in rank appraisal between 5-star hotel customers and hotel managers is in the area of the 'external environment'. This criterion is considered as the third most important by customers (in particular by female travellers whose primary concern is safety) but falls into sixth or last position of the 'customer' perspective in the mind of hotel managers. In fact, hotel managers have little influence on the external environment whilst customers can simply book another hotel if they are not attracted by a hotel's external environment. 
The tangible offer of a modern hotel goes beyond the provision of a room. Ancillary 'hotel facilities' such as restaurants and wellness centres enhance the guest experience and offer owners/managers the opportunity to increase revenue. The provision of 'hotel facilities' actually saw a convergence in rank order (no. 4) and weighting between demand- and supply-side responses.

\subsection{The 'learning and growth' (employee) perspective}

The relevance of employee relations, performance, management, motivation, training and development in the hospitality sector cannot be underestimated given the relatively high labour input. Hotels have, in recent years, seen a modicum of automation but this has mainly revolved around computerised internet booking engines.

Whereas relative congruence between the weightings given by customers and managers relating to 'customer' drivers was noted in the preceding section, results from both surveys, as shown in Figure 4, also show congruence between consumer and management respondents on issues relating to the 'learning \& growth' (employee) perspective, with the exception of 'good management'.

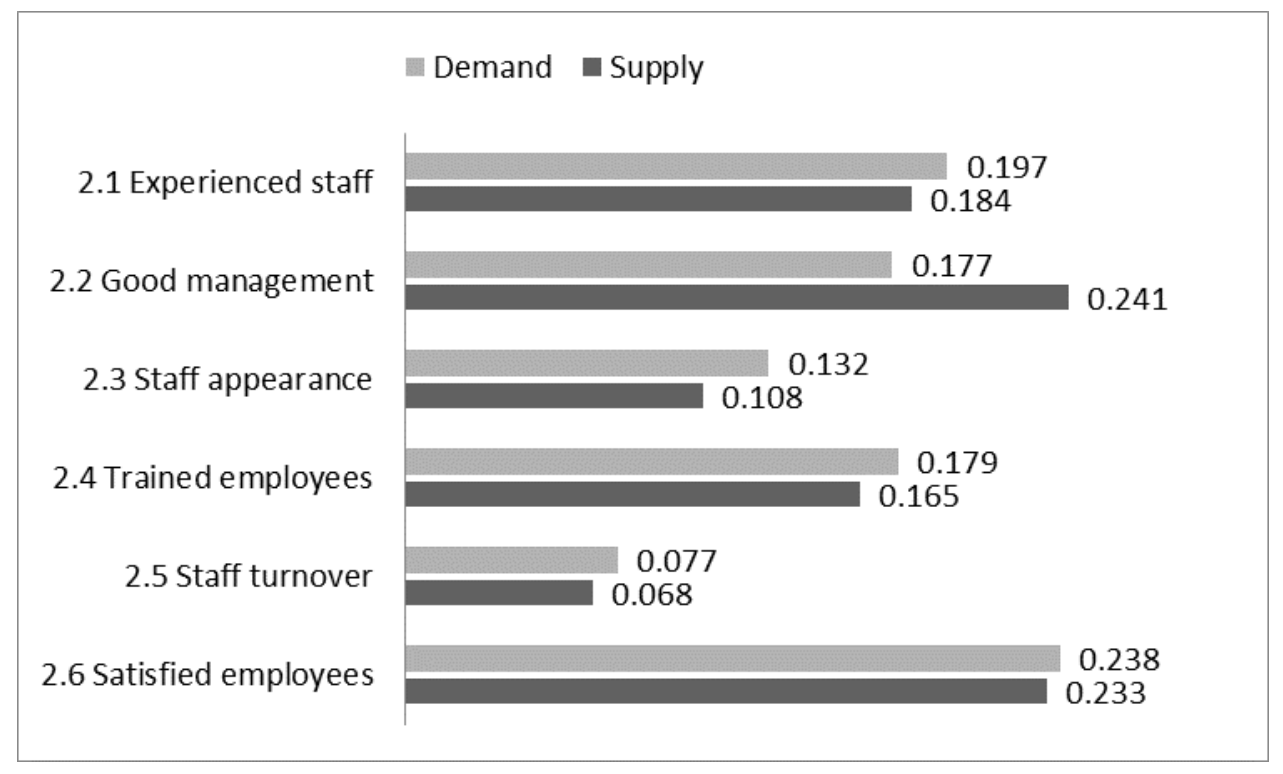

Figure 4. Employee perspective: demand- and supply-side weightings.

Within the employee perspective, 'staff appearance' is in fifth ranking, indicating a poor weighting by both customers and managers. This contrasts with the results of previous studies in the USA (Martin and Groves, 2002) and in the UK (Nickson et al., 2005). Demand- and supply-side surveys, particularly the latter, indicated that there exists little concern about the relevance of controlling 'staff turnover'. Staff turnover benchmarks in the hospitality industry is generally very high: from 60 to $300 \%$ according to research conducted by the American Hotel and Motel Association (CHA- 
international, 2009). Malta 5-star hotels have only a 6\% turnover (Deloite, 2015), which is much lower and therefore is not seen as an issue.

\subsection{The 'internal business process' perspective}

The 'internal business process' is the critical link between the customer and the productive source which, in hospitality, is primarily the employee input. These are referred to as Moments of Truth in the seminal work of the same name by Carlzon (1987) or more recently as customer experience touch points (Stein and Ramaseshan, 2016). Indeed, they are 'moments of truth' as the customer and employee interaction can make or break their relationship and determine the satisfactory stay or otherwise in a particular hotel.

According to hotel customers (Figure 5), the most important internal process attribute is 'room cleanliness'. Similarly, surveyed hotel managers gave this criterion the highest weighting within the 'internal business process' perspective.

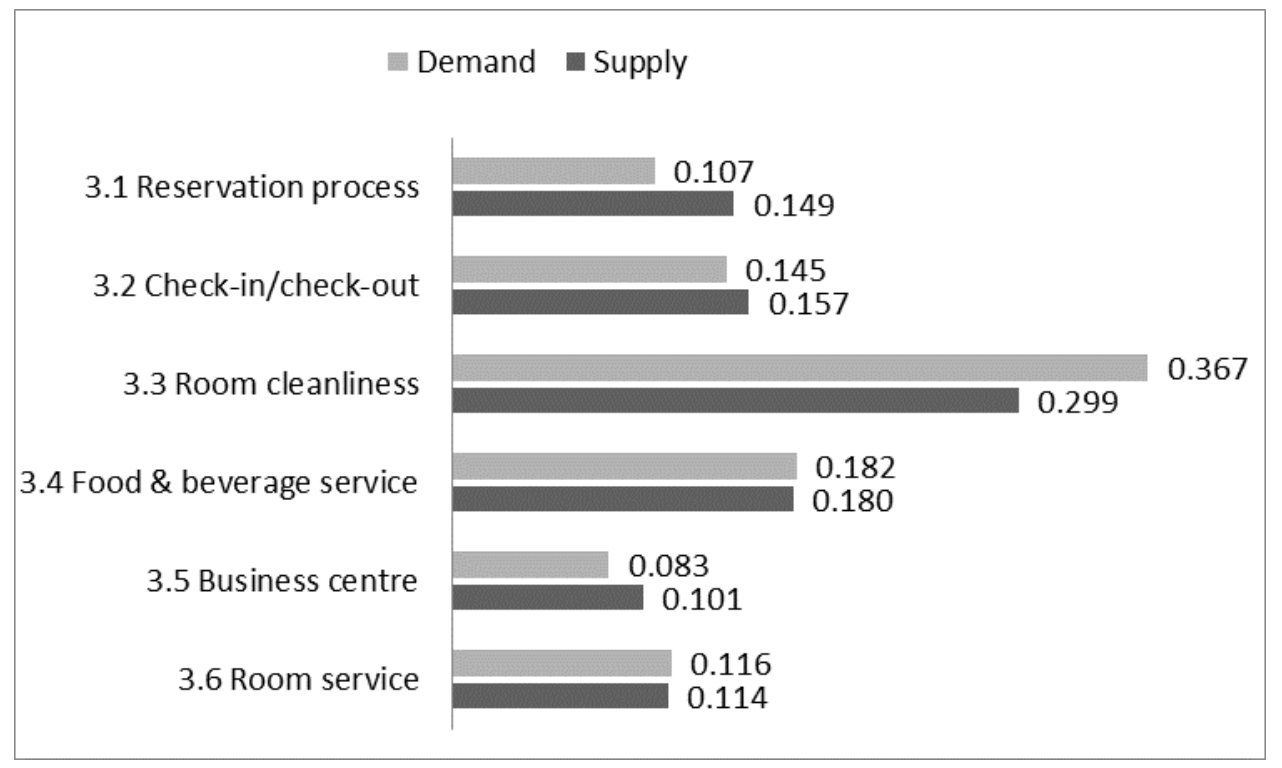

Figure 5. Internal process perspective: demand- and supply-side weightings.

Customers and managers alike are also in unison on second ranking being 'food \& beverage' service. The keyword in this perspective is 'service' so by this criterion, customers and managers alike are relating to 'food \& beverage' service delivery. Price considerations of 'food \& beverage' are tackled under the 'financial' perspective. The availability of 'room service' is a traditional musthave in 5-star hotels (Mohsin and Lockyer, 2010). However, this study shows that both demandand supply-sides of the sector have relegated 'room service' to fourth and fifth ranking respectively within the internal process perspective and therefore is not considered a decisive criterion. One could identify this result as the "Airbnb - effect", whereby levels of service quality 
and what used to be anticipated within certain hospitality environments has been eroded by the experience visitors expect to receive at a typical Airbnb unit. Similarly, hoteliers and hotel managers have learned to adjust their service offerings accordingly (Mody and Gomez, 2018).

In third position of the customer-ranking, we find the 'check-in and check-out' criterion. Both procedures are critical moments of truth since, a hotel experience may be positive for the duration of the stay and in the last value-chain link, at check-out, the system fails. The human intervention reservation process is another anachronism given the development and wide-spread use of internet booking engines. Hotel managers ranked 'reservation process' a notch higher than customers in fourth ranking. Until recently a 'business centre' was considered to be a must-have in any 'superior' hotel (Whitla et al., 2007). Hotels invested money, staff, and precious space to make available a 'business centre'. Major advances in technology have been made with mobile smart phones and tablets becoming every person's portable 'business centre'. Irrespective of whether hotel guests are on a business or leisure trip (or a combination of the two) they wish to stay connected. It is therefore not surprising that both demand- and supply-side stakeholders in hospitality agree that a 'business centre' is no longer a priority and does not influence the room price (Chen and Rothschild, 2010).

\subsection{The 'financial' perspective}

As illustrated in Figure 6, the most important criterion in the hospitality balanced scorecard, according to customers and hotel managers alike, is the 'room rate'. This is corroborated by similar studies that also revealed a high propensity to book depending on room rate (Schwartz and Chen, 2010). A similar conclusion is reached by (Ramanathan and Ramanathan, 2011) who looked at the room rate as an important determinant of guest loyalty. Repetti et al. (2015) and Tanford et al. (2012) also highlighted that room pricing is the most decisive criterion.

Customers and hotel managers also agree that the second most important 'financial' consideration in choosing a 5-star hotel is the cost of 'food and beverage'. The room component and food \& beverage are complementary, in the spirit of the accepted definition of 'hospitality' as the provision of overnight accommodation, food and drink (Brotherton, 1999). All other criteria are ranked further down the list by both customers and hotel managers. 


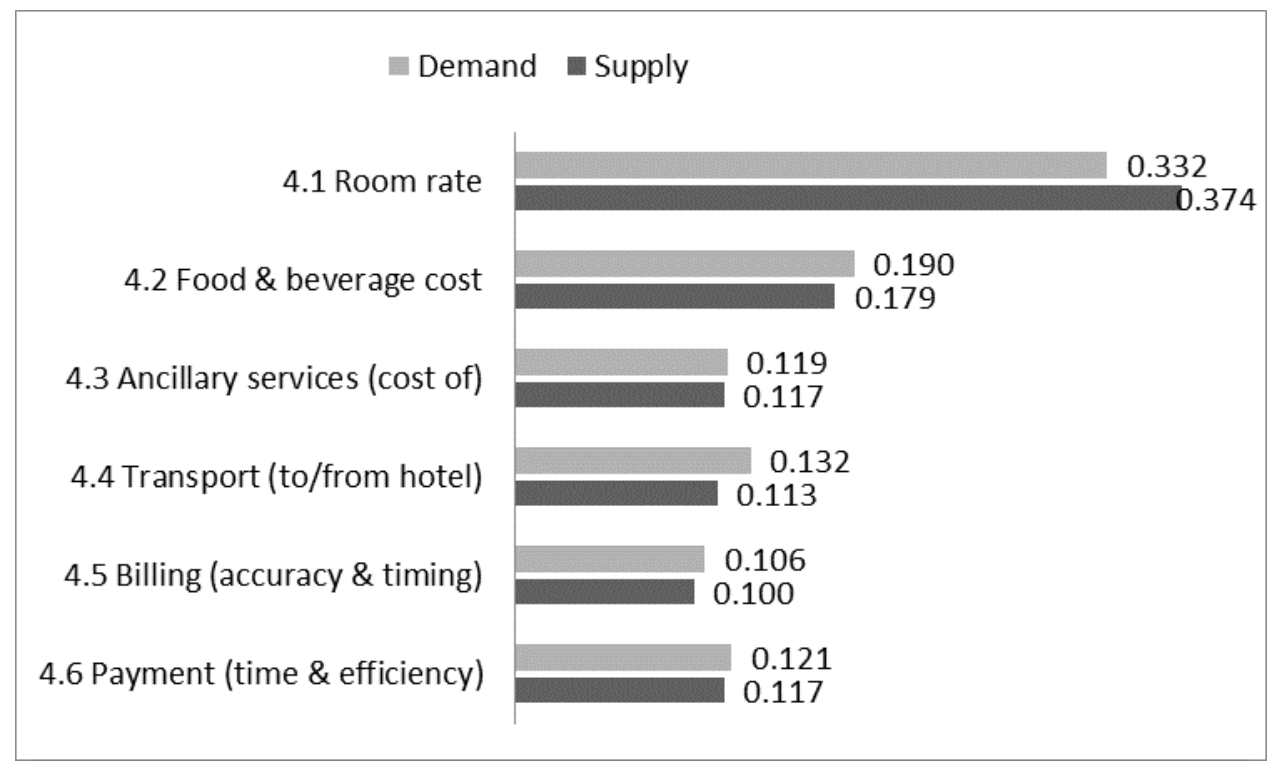

Figure 6. Financial perspective: demand- and supply-side weightings.

\subsection{Customer and management survey results compared}

To understand if hotel managers are in line with their customers' priorities, it is relevant to compare the weightings and resultant rankings from the customer survey with those of the management survey, irrespectively of the framing of the four balanced scorecard perspectives. The overall weightings indicated in Table 6 are given by the weightings derived from the AHP analysis (Figures 3 to 6) multiplied by the 'upper level' of the hierarchy (Figure 2) which are the AHP weightings of the four balanced scorecard perspectives (Figure 1).

As indicated in Figure 7, there is a significant positive correlation between the customer and management weightings, as testified by the Spearman Rank order correlation coefficient $(r=0.77$, $n=24, p<0.01$ ). This therefore indicates that the surveyed hotel managers are in tune with the criteria identified as important by their clients.

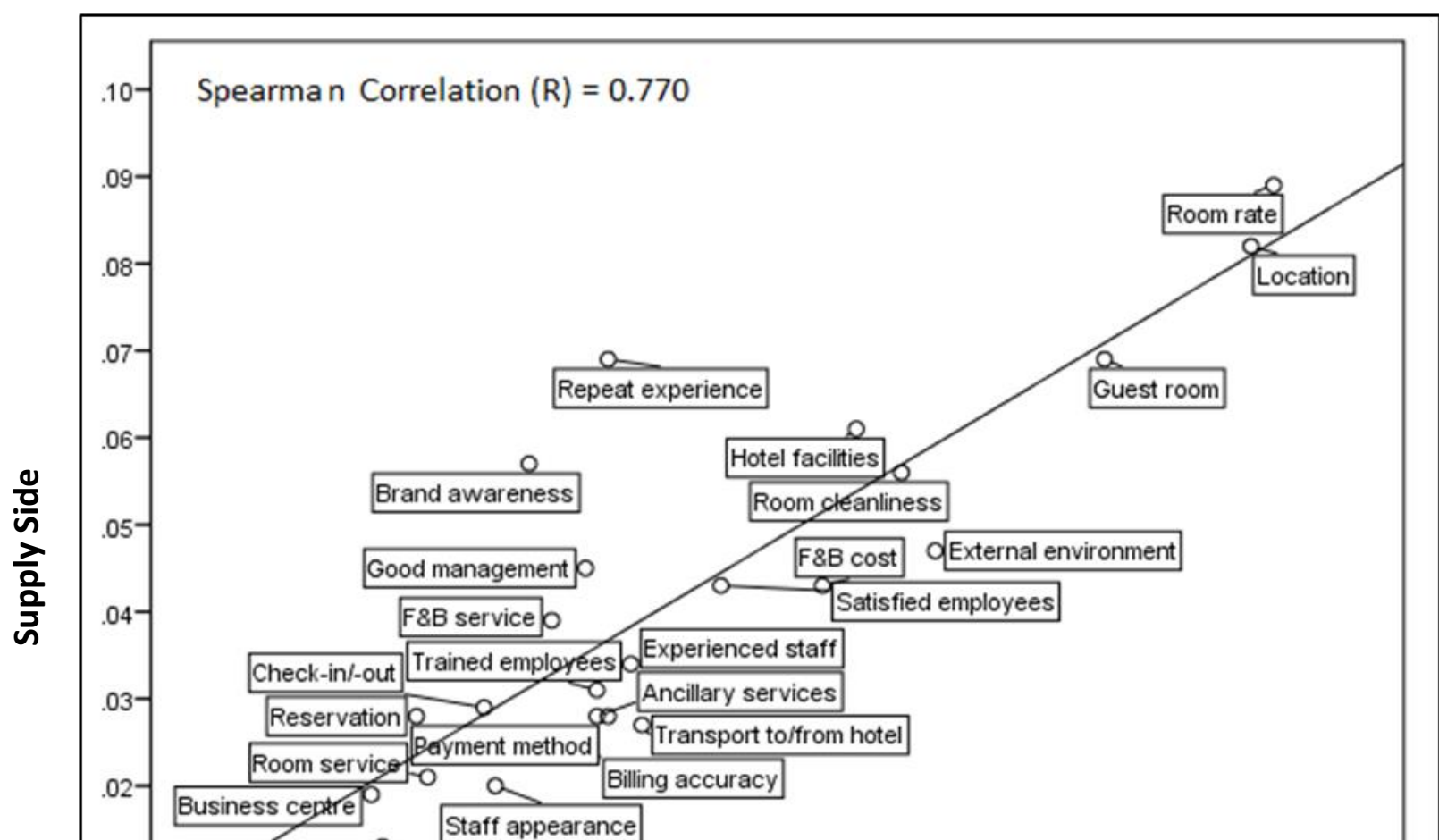


Figure 7. Graphical analysis of Spearman correlation between demand- and supply-side weightings.

Overall it is the 'room rate' that carries the highest weighting for both hotel guests and managers alike. This is an interesting finding given the fact that we would have expected this outcome to appear on lower quality hotels. Instead, it appears that superior quality hotels' guests in Malta seem to be equally sensitive to price fluctuations as the majority of visitors to the island (Blake et al., 2003, Durbarry and Sinclair, 2002). From this piece of finding, one could conclude that the high end of tourism demand in Malta tends to be as price sensitive as the rest of tourism demand on the island.

This is closely followed by 'location' and, in third place, the 'guest room', again for both hotel guests and management. There is a significant difference in the weighting and relevance ranking attributed to the 'external environment'. It ranks in $4^{\text {th }}$ position according to hotel guests, bolstered by female guests as explained in Section 4.2, whereas hotel managers do not consider it a priority giving the 'external environment' of the hotel a low weight and an $8^{\text {th }}$ overall ranking.

\section{Table 6 Overall ranking of decision-choice criteria}

\begin{tabular}{|l|l|l|l|l|l|}
\hline Criteria & $\begin{array}{l}\text { Customer } \\
\text { weighting }\end{array}$ & $\begin{array}{l}\text { Customer } \\
\text { ranking }\end{array}$ & $\begin{array}{l}\text { Management } \\
\text { weighting }\end{array}$ & $\begin{array}{l}\text { Management } \\
\text { ranking }\end{array}$ & $\begin{array}{l}\text { Difference } \\
\text { in weighting }\end{array}$ \\
\hline Room rate & 0.094 & 1 & 0.089 & 1 & 0.005 \\
\hline Location & 0.092 & 2 & 0.082 & 2 & 0.010 \\
\hline Guest room & 0.079 & 3 & 0.069 & 3 & 0.010 \\
\hline External environment & 0.064 & 4 & 0.047 & 8 & 0.017 \\
\hline Room cleanliness & 0.061 & 5 & 0.056 & 7 & 0.005 \\
\hline Hotel facilities & 0.057 & 6 & 0.061 & 5 & -0.004 \\
\hline F\&B cost & 0.054 & 7 & 0.043 & 11 & 0.011 \\
\hline Satisfied employees & 0.045 & 8 & 0.043 & 10 & 0.002 \\
\hline
\end{tabular}




\begin{tabular}{|l|l|l|l|l|l|}
\hline Transport to/from hotel & 0.038 & 9 & 0.027 & 19 & 0.011 \\
\hline Experienced staff & 0.037 & 10 & 0.034 & 13 & 0.003 \\
\hline Payment method & 0.035 & 11 & 0.028 & 16 & 0.007 \\
\hline Repeat experience & 0.035 & 12 & 0.069 & 4 & -0.034 \\
\hline Trained employees & 0.034 & 13 & 0.031 & 14 & 0.003 \\
\hline Ancillary services & 0.034 & 14 & 0.028 & 17 & 0.006 \\
\hline Good management & 0.033 & 15 & 0.045 & 9 & -0.012 \\
\hline F\&B service & 0.030 & 16 & 0.039 & 12 & -0.009 \\
\hline Billing accuracy & 0.030 & 17 & 0.024 & 20 & 0.006 \\
\hline Brand awareness & 0.028 & 18 & 0.057 & 6 & -0.029 \\
\hline Staff appearance & 0.025 & 19 & 0.020 & 22 & 0.005 \\
\hline Check-in/-out & 0.024 & 20 & 0.029 & 15 & -0.005 \\
\hline Room service & 0.019 & 21 & 0.021 & 21 & -0.002 \\
\hline Reservation & 0.018 & 22 & 0.028 & 18 & -0.010 \\
\hline Staff turnover & 0.015 & 23 & 0.013 & 24 & 0.002 \\
\hline Business centre & 0.014 & 24 & 0.019 & 23 & -0.005 \\
\hline
\end{tabular}

At the end of the scale, in terms of the 24 criteria in selecting a 5-star hotel, both hotel guests and hotel managers considered as relatively unimportant attributes such as the provision of 'room service', 'staff turnover' and, least relevant of all, the provision of a 'business centre'.

\section{Discussion and conclusion}

This paper outlines the outcome of a research effort that contributes towards the elicitation and prioritisation of decision-choice criteria considered by travellers in the hospitality sector. The twenty-four choice criteria elicited via focus groups were framed in the four perspectives of the balanced scorecard and prioritised using the AHP. The results of the Prioritised scorecard (PSC), a new hybrid BSC+AHP method, are deemed robust, particularly in relation to similar shorter-term studies, given the one year survey period that targeted the broad range of hotel guest source markets and purpose of visit. Furthermore, the elicited choice criteria were also subjected to prioritisation by hotel managers and the two survey results correlated. A marked convergence is noted indicating that the surveyed 5-star hotel managers in Malta are in tune with the criteria of their customers resulting in a satisfied guest. This congruence in turn translated into a positive sector-wide financial performance.

This study has also practical implications for hospitality customers, hotel managers and policy makers. Twenty-four criteria were elicited and prioritised in the four perspectives of the balanced scorecard. This framework should help hotel managers to identify weak areas of hotel performance and improve them. For this purpose, they can optimise the allocation of scarce resources in accordance with customer expectations and stakeholders' objectives. If there are discrepancies between the two parties, then the hotel managers need to align to what the 
customers want. However, this requires some further studies. In fact, a service delivery is affected through an 'internal business processes' which are composed of several touch-points (or interfaces) between employees and customers. Management can design a value stream mapping and concentrate on the critical touch-points that need most attention. This study has also implications for broader policy makers. The hospitality sector, especially in a small island such as Malta, needs adequate planning for zoning policies focused on the elicited criteria and then design customer-centric staff training programmes.

Finally, the findings of this study are a clear message to managerial stakeholders in the hospitality industry. Being in tune with and paying attention to customer decision choice criteria pays dividends, as shown by the customer-centric attitude of 5-star hotel managers in Malta that, in turn, is translating into a most positive financial performance.

\section{Theoretical implications}

The theoretical implications of this paper are two-fold. The first implication is related to hybrid approaches in modelling. The paper provides an integrated hybrid model of AHP and BSC, as opposed to hybrid modelling. As mentioned by Stephen and Labib (2018) at a theoretical level, a 'hybrid model' is mainly about a procedure; an output of one technique becomes an input to the subsequent technique. On the other hand, 'hybrid modelling' is about the use of independent techniques to study the same problem in different ways. Such classification of hybrid model as opposed to hybrid modelling was originally proposed by Shanthikumar and Sargent (1983). Hence the paper contributes to hybrid model and complements the application of other hybrid models in other applications (Stephen and Labib, 2018, Labib and Read, 2015, Ishizaka and Labib, 2014, Ishizaka et al., 2016, Ishizaka and Nemery, 2013).

The second theoretical implication, as mentioned earlier on is that the paper questions the very term 'balanced' in the Balanced Scorecard, which has been assumed to imply that the four dimension of BSC are equally important, whereas our analysis has demonstrated that the dimensions of the BSC have different weights based on the perspectives from customers and service providers. So, we argue that the term 'balanced' implies the opposite to the term 'biased'. So that there is a balance between quantitative versus qualitative, financial versus non-financial, retrospective versus prospective views, and so on, but their importance (weights) are not the same.

\section{Managerial implications}

Some of the results of this study are of major relevance to owners, managers of 5-star hotels and practitioners, in their quest to meet and exceed customer expectations. Hospitality managers can use these results, derived by the merger of balanced scorecard tenets and AHP, in their decisionmaking, particularly with regard to customer-related issues. Furthermore, the above results are 
also of particular value to those entrusted with policy making in hospitality and destination management.

\subsection{Practical implications for hotel managers}

From a supply-side perspective, the research findings offer a number of practical implications. The following are the key practical implications sourced from this study of relevance to hotel managers:

a) Customer perspective: The traditional balanced scorecard does not provide information on the relative importance of the criteria that compose each of the four perspectives. With the help of the AHP, the balanced scorecard perspectives and criteria are prioritised. Customer perspective is the most important perspective. This is logical because without customer, no business is viable.

b) Room rate: Surveyed demand and supply sides agree on the most important criterion: the room rate. A study has shown that there is an inverse U-shaped relationship between price (room rate) and guest satisfaction (Chen et al., 2015). This non-linear relationship is due to the double effect of price on satisfaction: one positive as an indicator of product quality and a second as an indicator of sacrifice (Campo and Yagüe, 2008). Accordingly, a medium price tends to be preferred indicating to 5-star hotel managers that they need to consider the room rate level most carefully. To assist them, hotel revenue (yield) management systems need to be in place to help them define best pricing strategies (Ivanov and Zhechev, 2012).

c) Resource allocation: In the hospitality industry, resources are often scarce and competition fierce. These characteristics are even more amplified in the context of a small island state such as Malta given its peripheral insularity and high economic vulnerability. It is therefore important to optimize the use of scarce resources. The hybrid combination of balanced scorecard and AHP presented here allows hotel managers to allocate resources in accordance with customer-ranked criteria whilst at the same time prioritizing stakeholders' objectives.

\subsection{Public policy implications}

Governments and local authorities have a responsibility to set public policy on travel and tourism in general as well as planning at sector level in such areas as transport and hospitality. A number of public policy implications of the findings highlighted herein are the following:

a) Development zoning: The study reconfirmed 'location' as a major criterion in the selection of a 5-star hotel by guests and managers alike. Zoning allows setting real or imaginary divisions of a territory according to the area's features that may include, inter alia, climatic conditions, landscape value, a nature park, connectivity, heritage sites, recreational 
facilities and similar (Mirzekhanova and Debelaia, 2015). The Malta, Comino and Gozo islands of Malta represent a limited territory, necessitates adequate zoning policies by the central Government and local planning authorities through the designation of land areas where tourism accommodation is permitted, guided by the over-riding principles of sustainable tourism development. Such development zoning has already been proposed for the Marsaxlokk Bay area in the south of Malta (Spiteri, 2011).

b) Sector policy and planning: Small islands have often limited development options. Malta features a high economic dependency upon tourism, therefore the sector policy and planning is highly important. The hospitality sector exhibits a strong contribution to the tourism sector in Malta (Azzopardi and Nash, 2016). The prioritised criteria that customers expect from a superior hotel elicited from this study can inform the formulation of an Accommodation Policy and Plan for the destination.

c) Hotel classification standards: Hotel classifications have been established to help customers to match their expectations. However, official hotel classification systems vary between member states causing confusion not only for tourists but also to the whole hospitality sector (Cser and Ohuchi, 2008). The European Union is seriously considering to develop a single classification system that can be applied to all countries (Rhee and Yang, 2015). The criteria and their respective weightings elicited and prioritised in this study can inform hotel classification standards, based as they are on the opinion of the most important stakeholder of all: the customer.

\section{Limitations and future study recommendations}

This study has also its limitations. First, the response rate of the managers is quite low. They represent only a small part of the whole sector (just above 16\%). The response rate for the customer is a bit higher with $26 \%$. These response rates are usual for surveys but a higher response rate could give a better picture.

It is also to note that this study took place in one tourism destination, Malta. Therefore, future similar studies could explore the extent of the correlation (or lack of it) between customer and management criteria in other destinations.

The hybrid AHP-Prioritised scorecard is a generic method. It can easily be used in other sectors, where the four perspectives are not considered equivalent. As further research, it can also be envisaged to use other weighting techniques to prioritise the balanced scorecard.

\section{References}

Akincilar, A. and Dagdeviren, M. (2014), "A hybrid multi-criteria decision making model to evaluate hotel websites", International Journal of Hospitality Management, Vol. 36, pp. $263-271$ 
Assaf, G. Josiassen, A., Kneẑevic Cvelbar,L. and Wood, L. (2015), "The effects of customer voice on hotel performance", International Journal of Hospitality Management, Vol.44, pp. $77-83$

Azzopardi, E. and Nash, R. (2016), "A framework for island destination competitiveness - perspectives from the island of Malta", Current Issues in Tourism, Vol. 19, pp. 253-281

Babayan, N. Daros, L. and Mascarell, C. (2014), "Financial performance of Spanish hotels during the crisis", Working Papers on Operations Management, Vol.5, pp. $15-30$

Blake, A.Sinclair, M. and Sugiyarto, G. (2003), "The Economic impact of tourism in Malta: Input - output modelling: A report for the Malta Tourism Authority", Nottingham University Business School

Brotherton, B. (1999), "Towards a definitive view of the nature of hospitality and hospitality management", International Jourinal of Contemporary Hospitality Management, Vol. 11, pp. 165 - 173

Callarisa, L. García, J. Cardiff, J. and Roshchina, A. (2012), "Harnessing social media platforms to measure customer - based hotel brand equity", Tourism Management Perspectives, Vol. 4, pp. $73-79$

Campl, S. and Yagüe, M. (2008), "Effects of price on tourist satisfaction", Tourism Economics, Vol. 14, pp. $657-661$

Carlzon, J. (1987), Moments of truth, Cambridge, Massachusetts, Ballinger Publishing Company

cha - international. (2009), "The employee turnover? The Challenge", available at: http://www.chainternational.com/The-Hotel-Employer-Turnover, (Accessed 15/02/2019 2016)

Chen, C.F. and Rothschild, R. (2010), "An application of hedonic pricing analysis to the case of hotel rooms in Taipei", Tourism Economics, Vol. 16, pp. 685-694

Chen, C.M. Yang, H.W. Li, E. and Liu, C.C. (2015), "How does hotel pricing influence guest satisfaction by the moderating influence of room occupancy?", International Journal of Hospitality Management, Vol. 49, pp. $136-138$

Chen, Y.C. Yu, T.H. Tsui, P.L. and Lee, C.S. (2012), “A fuzzy AHP approach to construct international hotel spa atmosphere evaluation model, Quality and Quantity, Vol. 48, pp. $645-657$

Clinton, B.D. Webber, S.A. Hassell, J.M. (2002), "Implementing the balanced scorecard using the analytic hierarchy process", Management Accounting Quarterly, Vol. 3(3), pp. 1-11

Cser, K. and Ohuchi, A. (2008), "World practices of Hotel Classification Systems", Asia Pacific Journal of Tourism Research, Vol. 13, pp. $379-398$

Deloitte (2018), The Bov Mhra survey report Q4 2017 and YTD, Malta: Malta hotels and restaurants association

Durbarry, R. and Sinclair, M. (2002), "The price sensitivity of tourism demand in Malta: A report for the Malta tourism authority", Nottingham: Nottingham University Business School.

Elbanna, S. Eid, R. and Kamel, H. (2015), "Measuring hotel performance using the balanced scorecard: A theoretical construct development and its empirical validation", International Journal of Hospitality Management, Vol. 51, pp. $105-114$ 
Emir, O. and Saraçli, S. (2014), "Determination of the thermal hotel location: Application of Analytic Hierarchy Process", Tourism and Hospitality Management, Vol. 20, pp. $71-83$

Fabac, R. and Zver, I. (2011), "Applying the modified SWOT-AHP method to the tourism of Gornje Medimurje", Tourism and Hospitality Management, Vol. 17, pp. $201-215$

Fu, H.P. Chu, K.K. Chao, P. Lee, H.H. and Liao, Y.C. (2011), "Using fuzzy AHP and VIKOR for benchmarking analysis in the hotel industry", The Services Industries Journal, Vol. 31, pp. 2373 - 2389

Harris, J.R. Guffey, H.J. Laumer, J.F. (1979), "The windshield method of questionnaire distribution: A viable alternative", Journal of the Academy of Marketing Science, Vol. 7, pp. 184-191

Hsiao, T.-Y. Tsai, H.-Y. Lockyer, T. Sung, P.-L. and Kuo, S.-Y. (2018), "Factors for development of bed and breakfast management in Taiwan", Anatolia, advance online publications, 10.1080/13032917.2018.1430043.

Ip, C. Law, R. and Lee, H. (2012), "The evaluation of hotel website functionality by Fuzzy Analytic Hierarchy Process", Journal of Travel and Tourism Marketing, Vol. 29, pp. 263-278

Ishizaka, A. and Labib, A. (2011), "Review of the main developments in the analytic hierarchy process", Expert Systems with Applications, Vol. 38, pp. $14336-14345$

Ishizaka, A. and Nemery. P. (2013), "A multi-criteria group decision framework for partner grouping when sharing facilities", Group Decision and Negotiation, Vol. 22(4), pp. 773-799

Ishizaka, A. and Labib, A. (2014), "A hybrid and integrated approach to evaluate and prevent disasters", Journal of the Operational Research Society, Vol. 65 , pp. 1475-1489

Ishizaka, A. and Siraj, S. (2018), "Are multi-criteria decision-making tools useful? An experimental comparative study of three methods", European Journal of Operational Research, Vol. 264(2), pp. 462-471

Ishizaka, A Siraj, S. and Nemery, P. (2016), "Which energy mix for the UK (United Kingdom)? An evolutive descriptive mapping with the integrated GAIA (graphical analysis for interactive aid)-AHP (analytic hierarchy process) visualisation tool", Energy, Vol. 95, pp. 602-611

Ivanov, S. and Zhechev, V. (2012), "Hotel revenue management - a critical literature review", Tourism: An International Interdisciplinary Journal, Vol. 60, pp. 175 - 197

Jackson, L. and Qu, H. (2008), "A Conceptual Framework for Managing Lodging Brands: A Balanced-Scorecard Approach", Journal of Quality Assurance in Hospitality and Tourism, Vol. 9, pp. 108 134

Juan, P.J. and Lin, S.Y. (2013), "Selecting resort locations", Tourism Economics, Vol. 19, pp. 1249 - 1272

Kang, J.C. Chiang, C.F. Huangthanapan, K. and Downing, S. (2015), "Corporate social responsibility and sustainability balanced scorecard: The case study of family-owned hotels", International Journal of Hospitality Management, Vol. 48, pp. $124-134$

Kaplan, R. (2008), "Conceptual foundations of the balanced scorecard ", In: Chapman, C. Hopwood, A. and Shields, M. (Eds.), Handbook of Management Accounting Research, Elsevier: London 
Kaplan, R. and Norton, D. (1996), The Balanced scorecard: Translating Strategy into Action, Boston, Harvard Business School Publishing

Kim, Y. Chung, B. Kwon, K. and Sukmaungma, S. (2014), "The application of the modified balanced scorecard advanced hierarchy process extended to the economy, upscale, and luxury hotels' websites", Anatolia Journal, Vol. 25, pp. $81-95$

Labib, A. and Read, M. (2015), "A hybrid model for learning from failures: The Hurricane Katrina disaster", Expert Systems with Applications, Vol. 42 , pp. 7869-7881

Law, R. Leung, R. Lo, A. Leung, D. and Fong, L. (2015), "Distribution channel in hospitality and tourism: Revisiting disintermediation from the perspectives of hotels and travel agencies", International Journal of Contemporary Hospitality Management, Vol. 27, pp. 431 - 452

Lee, T. and Liu, R. (2011), "Strategy formulation for the recreational areas of Central Taiwan: An application of SWOT (strengths, weaknesses, opportunities, threats) analysis", Journal of Hospitality Management and Tourism, Vol. 2, pp. $38-47$

Lin, S. and Lin, H. (2011), "Organizational performance measurement system and international tourist hotels: A new conceptual framework", Journal of Testing and Evaluation, Vol. 39, pp. $269-277$

Martin, L. and Groves, J. (2002), "Interviews as a selection tool for entry-level hospitality employees", Journal of Human Resources in Hospitality and Tourism, Vol. 1, pp. $41-47$

MHRA, (2010), "The BOV MHRA Survey Report Q4 2009 and YTD”, In: Association, M.H.R. (Ed.), Malta: Deloitte

MHRA, (2018), "The BOV MHRA Survey Report Q4 2017 and YTD”, In: Association, M.H.R. (Ed.), Malta: Deloitte

Millet, I. (1997), "The effectiveness of alternative preference elicitation methods in the Analytic Hierarchy Process", Journal of Multi-Criteria Decision Analysis, Vol. 6, pp. $41-51$

Mirzekhanova, Z. and Debelaia, I. (2015), "Tourism zoning of area for sustainable development of the example of Khabarovsky Krai", Meditteranean Journal of Social Sciences, Vol. 6, pp. 283-288

Mody, M. and Gomez, M. (2018), "AirBnB and the Hotel Industry: The Past, Present and Future of Sales, Marketing, Branding and Revenue Management", Boston Hospitality Review, Vol. 6 No. 3

Mohsin, A. and Lockyer, T. (2010), "Customer perceptions of service quality in luxury hotels in New Delhi, India: An exploratory study", International Journal of Contemporary Hospitality Management, Vol. 22, pp. $160-173$

Nickson, D. Warhurst, C. and Dutton, E. (2005), "The importance of attitude and appearance in the service encounter in retail and hospitality", Managing Service Quality: An International Journal, Vol. 15, pp. 195 208

NSO, (2007), Departing Tourists: December 2006, Valletta: National Statistics Office Malta

NSO, (2018), Departing Tourists: December 2017, Valletta: National Statistics Office Malta 
Pizam, A. Shapoval, V. and Ellis, T. (2016), "Customer satisfaction and its measurement in hospitality enterprises: A revisit and update", International Journal of Contemporary Hospitality Management, Vol. 28, pp. $2-35$

Ramanathan, U. and Ramanathan, R. (2011), "Guests' perceptions on factors influencing customer loyalty: An analysis for UK hotels", International Journal of Contemporary Hospitality Management, Vol. 23, pp. 7 25

Repetti, T. Roe, S. and Gregory, A. (2015), "Pricing strategies for resort fees: Consumer preferences favor simplicity", International Journal of Contemporary Hospitality Management, Vol. 27, pp. 790 - 809

Rhee, H. and Yang S.B. (2015), "Does hotel attribute importance differ by hotel? Focusing on hotel starclassifications and customers' overall ratings", Computers in Human Behaviour, Vol. 50, pp. 576-587

Roy, J. Chatterjee, K. Bandyopadhyay, A. and Kar, S. (2018), "Evaluation and selection of medical tourism sites: A rough analytic hierarchy process based multi-attributive border approximation area comparison approach" Expert Systems, Vol. 35 No.1, e12232. https://doi.org/10.1111/exsy.12232

Sainaghi, R. Phillips, P. and Corti, V. (2013), "Measuring hotel performance: Using a balanced scorecard perspectives' approach", International Journal of Hospitality Management, Vol. 34, pp. $150-159$

Saaty, T.L. (1980), "The Analytic Hierarchy Process: Planning, Priority Setting, Resource Allocation, McGrawHill: New York

Saaty, T.L. and Vargas, L.G. $\left(2012,2^{\text {nd }}\right.$ ed.), "Models, Methods, Concepts \& Applications of the Analytic Hierarchy Process, Springer: New YorkSchwartz, Z. and Chen, C. (2010), "The peculiar impact of higher room rates on customers' propensity to book", International Journal of Contemporary Hopsitliaty Management, Vol. 22, pp. $41-55$

Shahin, A. Pool, J. and Poormostafa, M. (2014), "Evaluating and ranking hotels offering e-service by integrated approach of Webqual and fuzzy AHP", International Journal of Business Information Systems, Vol. 15, pp. $84-104$

Shanthikumar, J. G. and Sargent, R. G. (1983). "A unifying view of hybrid simulation/ analytic models and modelling", Operations Research, Vol. 31 No. 6, pp. 981-1197.

Sharma, M. and Bhagwat, R. (2007), "An integrated BSC-AHP approach for supply chain management evaluation", Measuring Business Excellence, Vol. 11, pp. 57-68

Shirouyezad, H. Lotfi, F. Arabzad, D. and Dabestani, R. (2013), "An AHP/DEA ranking method based on service quality approach: A case study in hotel industry", International Journal of Productivity and Quality Management, Vol. 11, pp. $434-445$

Skinner, D. (2009), "Introduction to decision analyis: A practitioner's guide to improving decision quality", Probabilistic Publishing: Gainesville

Sohrabi, B. Vanani, I. Tahmasebipur, K. and Fazli, S. (2012), "An exploratory analysis of hotel selection factors: A comprehensive survey of Tehran hotels", International Journal of Hospitality Management, Vol. 31, pp. $96-106$

Spiteri, B. (2011), "Towards sustainable management of land and sea uses within the Marsaxlokk Bay area", Journal of Coastal Research, Vol. 61, pp. $242-247$ 
Stein, A. and Ramaseshan, B. (2016), "Towards the identification of customer experience touch point elements", Journal of Retailing and Consumer Services, Vol. 30, pp. 8-19

Stephen, C. and Labib, A. (2018), "A hybrid model for learning from failures", Expert Systems with Applications, Vol. 93, pp. 212-222

Tanford, S. Raab, C. and Kim, Y.S. (2012), "Determinants of customer loyalty and purchasing behavior for full-service and limited-service hotels", International Journal of Hospitality Management, Vol. 31, pp. 319 328

Tsaur, S.H. and Lin, W.R. (2014), "Selection criteria of an overseas travel intermediary for group package tours: Application of fuzzy analytic hierarchy process", Journal of Hospitality and Tourism Research, Vol. 38, pp. $283-303$

Tsaur, S.H. and Tzeng, G.H. (1996), "Multiattribute Decision Making Analysis for Customer Preference of Tourist Hotels", Journal of Travel and Tourism Marketing, Vol. 4, pp. $55-69$

Whitaker, R. (2007), "Validation examples of the analytic hierarchy process and analytic network process", Mathematical and Computer Modelling, Vol. 46, pp. $840-859$

Whitla, P. Walters, P. and Davies, H. (2007), "Global strategies in the international hotel industry", International Journal of Hospitality Management, Vol. 26, pp. $777-792$

Wong, T. and Wickham, M. (2015), "An examination of Marriott's entry into the Chinese hospitality industry: A Brand equity perspective", Tourism Management, Vol. 48, pp. $439-454$ 